\section{Determination of phytoplank- ton in water samples, algal biotoxins, microbiological parameters and microplastics in Mediterranean mussels (Mytilus galloprovincialis Lamarck, 1819) from an experi- mental pilot farm in the Calich Lagoon (Sardinia, Italy)}

\author{
Alessandro Graziano Mudadu, ${ }^{1}$ \\ Anna Maria Bazzoni, ${ }^{2}$ Rita Melillo, ${ }^{1}$ \\ Giuseppa Lorenzoni, ${ }^{1}$ Gabriella Piras, ${ }^{1}$ \\ Sara Salza, ${ }^{1}$ Simona Cau, \\ Barbara Soro, ${ }^{1}$ Bruna Vodret, ${ }^{1}$ \\ Tiziana Tedde, ${ }^{1}$ Nicola Fois, ${ }^{3}$ \\ Simonetto Serra, ${ }^{3}$ Sebastiano Virgilio, ${ }^{1}$ \\ Domenico Meloni ${ }^{4}$
}

${ }^{1}$ Complex Structure of Microbiology and Inspection of Food of Animal Origin, Experimental Zooprophylactic Institute of Sardinia, Sassari; ${ }^{2}$ ARPAS - Regional Agency for Environmental Protection of Sardinia, Sassari; ${ }^{3}$ AGRIS SARDEGNA - Agency for Research in Agriculture, Bonassai Research Center, Olmedo (SS); ${ }^{4}$ Department of Veterinary Medicine, University of Sassari, Italia

\footnotetext{
Abstract

The aims of this paper were to collect and analyse preliminary data of phytoplankton in the water, biotoxins, Escherichia coli, Salmonella spp., Vibrio spp. and microplastic eventually present in farmed mussels, and to acquire information about the production capability from an experimental pilot farm of the Calich Lagoon. Two sampling sessions were carried out, in February and in May 2019, also monitoring the water condition ( $\mathrm{pH}$, temperature, salinity, dissolved oxygen, chlorophyll $a$ ). No potentially toxic algae were detected, and moreover no biotoxins (Paralytic Shellfish Poison, Diarrheic Shellfish Poison, Amnesic Shellfish Poison) were found in mussels. E.coli was present with the highest concentration in February (16000 MPN/100g e.p.). Salmonella and Vibrio spp. have not been detected. Almost a microplastic per grams was found, mainly fiber of different colours. Further studies, carried out for several months, will allow to better understand the possible problems related to the production of mussels in a lagoon not yet classified as a shellfish production area.
}

\section{Introduction}

Mediterranean wetland areas play an important economic part in the surrounding community, representing economic resources for fishing, agriculture, and touristic activities.

In Europe, the production of Mytilus species increased by $7 \%$, the Italian production contributing in 2018 with $64 \times 10^{3}$ tonnes (EUMOFA, 2018). In Sardinia the mollusc farming has a long history and is an important sector for the regional economy. The increased development of various forms of aquaculture in the Mediterranean lagoons (Cataudella et al., 2015), has raised the attention to multiple factors linked to climate change and variability that may affect food safety connected to shellfish consumption (Tirado et al., 2010). Molluscs may be contaminated because of their nature as suspension feeders, by taking phytoplankton, zooplankton, bacteria, and inorganic matter from the surrounding water. Mussels can be a vehicle for the transmission of various diseases as a result of their consumption. In Europe the sanitary control of shellfish produced and sold for human consumption is based on the monitoring of Escherichia coli, considered a common indicator organism of faecal contamination in aquatic systems (Noble et al., 2004), and Salmonella spp. (Reg. (EU) No 625/17 , Reg. (EU) No 627/19, Reg. (EU) No 2073/05)

As reported in EFSA and ECDC (2021), Salmonella spp. is the second most common cause of human gastroenteritis. In the aquatic environment, there are commonly find Vibrio spp. (Thompson et al., 2004), some of which are involved in important infections, specifically Vibrio parahaemolyticus, Vibrio cholerae, and Vibrio vulnificus (Caburlotto et al., 2011). Equally important is the possible presence of algal biotoxins produced by potentially toxic harmful algal species, such as Paralytic Shellfish Poison (PSP), Diarrheic Shellfish Poison (DSP) and Amnesic Shellfish Poison (ASP). Microplastics (MPs) in the marine environment have become a major environmental concern over the last years (Tsangaris et al., 2021). Plastic are synthetic polymers, originated by the polymerization of organic and inorganic elements, such as carbon, silicon, hydrogen, oxygen and chloro (Shah et al., 2006), petroleum based (Thompson et al., 2009). A significant percentage of plastic produced in the world end up in the oceans (Thompson et al., 2009). Increasing attention has been paid by the researcher towards the presence of plastic fragments, defined by Arthur et al. (2009) microplastics, as particles with size inferior to $5 \mathrm{~mm}$. Bivalve
Correspondence: Melillo Rita, Istituto Zooprofilattico Sperimentale della Sardegna Struttura Complessa di Microbiologia e Ispezione degli Alimenti, Via Duca degli Abruzzi 8, Sassari, 07100, Italia.

Tel: +39.079.2892387

E-mail: rita.melillo@izs-sardegna.it

Key words: Mussels; Microplastic; Mediterranean lagoon; Food safety.

Contributions: The authors contributed equally.

Conflict of interest: The authors declare no conflict of interest

Funding: This work was funded by the EU Interreg program RETRALAGS (TRAnsfrontier network of LAGunes, lakes and ponds) 2014-2019 (Pilot Action T2.1.2 "Development of an experimental bivalve mollusc pilot farm in the Calich Lagoon").

Received for publication: 14 July 2021.

Accepted for publication: 12 January 2022.

This work is licensed under a Creative Commons Attribution-NonCommercial 4.0 International License (CC BY-NC 4.0).

(C) Copyright: the Author(s), 2022

Licensee PAGEPress, Italy

Italian Journal of Food Safety 2022; 11:9973

doi:10.4081/ijfs.2022.9973

molluscs are of particular interest because their feeding strategies expose them to particles present in the water column.

The main aims of the present study were: a) to evaluate the occurrence of different microorganisms (E.coli, Salmonella spp., Vibrio spp.), and items in Mitylus galloprovincialis from an experimental pilot farm of the Calich Lagoon, a Sardinian lagoon (Italy); b) to analyse the phytoplanktonic population in the lagoon water; c) to assess the possible presence of biotoxins in M. galloprovincialis.

\section{Materials and methods}

\section{Sampling and analysis}

Our study was carried out from February 2019 to May 2019, 1 sample of 2 liters (L) of lagoon water was sampled each month to analyse the present phytoplankton population. Water samples were taken using clean polyethylene bottles at a deep of 0.5 m. Two mussel samples (one in February 2019 and one another in May 2019) were collected and analysed to investigate the possible presence of different microorganisms (E. Coli, Salmonella spp.,Vibrio spp.) 
biotoxins, including domoic acid (DO, responsible for ASP), PSP group (responsible for PSP), LTs group (including Okadaic acid (OA) and its derivates), DTXs and associated esters (responsible for DSP) and besides: Pectenotoxins, Yessotoxin, Gimnotoxins, Spirolides, Pinnatoxins, Portimine and Azaspiracid (Wu et al., 2019). Possible presence of MPs was also investigated.

\section{Study area}

The Calich Lagoon is situated in the Porto Conte Regional Natural Park, along the north-western coast $\left(40^{\circ} 35^{\prime} 47.5^{\prime \prime} \mathrm{N}\right.$; $8^{\circ} 17^{\prime} 59.9^{\prime \prime}$ E) of Sardinia (Italy) (Figure 1). The lagoon extends for 92 ha with a depth varying between about 0.5 and $1.5 \mathrm{~m}$. It is connected with the Alghero Gulf through a natural channel (60-m wide and 2-m deep) hosting a medium size shipyard and a tourist harbour. The lagoon receives freshwater from two natural fluvial tributaries and an artificial channel (Pulina et al., 2017; Esposito et al., 2021). The Calich Lagoon suffers of high eutrophication due to urban, agricultural, and industrial activities (Fenza et al., 2014; Bazzoni et al., 2018). Its catchment area extends for about 42,000 ha, receiving water from several municipalities. Water temperature in the Calich Lagoon follows a seasonal trend with the highest values between July and August (Baralla et al., 2017). The Calich Lagoon is a highly productive environment (Bazzoni et al., 2019) and several studies (Chessa et al., 2005; 2007; Pais et al., 2006; 2007; Cannas et al., 2011; Serra et al., 2011) suggested that shellfish farming should be a sustainable exploitation strategy for this lagoon. Previous authors pointed out the occurrence of biological and chemical contaminants in native shellfish (Sedda et al., 2016; Baralla et al., 2017; Bazzoni et al., 2019; Esposito et al., 2018; 2021) and studied the ecology of different planktonic components (Ielmini et al., 2014; Pulina et al., 2017, 2018; Bazzoni et al., 2018; Satta et al., 2020).

Although the high abundance of natural beds of highly valuable commercial species of bivalves e.g., grooved carpet shell (Ruditapes decussatus), olive green cockle (Cerastoderma glaucum), and Mediterranean mussel (M. galloprovincial$i s$, the Calich Lagoon has not yet been classified as shellfish production area (Esposito et al., 2018; 2021; Bazzoni et al., 2019).

\section{Experimental mussel pilot farm}

The experimental mussel pilot farming was carried out in suspension, on a small "Trieste" type farm plant consisting of 2 single ropes supported by wooden poles fixed deeply in the muddy sediment of the lagoon and emerging from the water for about 1 meter. The mussels were inserted in n.60 droppers seeded with plastic stockings ( 80 cm length and $38 \mathrm{~mm}$ mesh) filled with tiny mussels $(\approx 3.5 \mathrm{~cm}$ length and $1.9 \mathrm{~cm}$ width). The experiment began in December 2018 and continued until the achievement of the minimum commercial size ( $5 \mathrm{~cm}$ in length).

\section{Water samples and phytoplankton analyses}

A total of four monthly water samples were analysed from February to May 2019 to identify and quantify the phytoplankton taxa present in the mussel breeding site. Two liters (L) of water samples were taken using clean polyethylene bottles, of which, $1 \mathrm{~L}$ was preserved in situ with Lugol's iodine to be used in the microalgal species counts and $1 \mathrm{~L}$ for in vivo observation of phytoplankton. Samples were delivered to the laboratory under refrigerated conditions. Accordance to the EU reference method UNI EN ISO 15204:2006, the cell count was performed by means of Utermöhl's method (1958) on settling chambers $\left(10 \mathrm{~cm}^{3}\right)$. An inverted microscope Olympus IX 73 (Olympus, Shinjuku, Tokyo, Japan) was utilized for the determination and enumeration of phytoplankton at magnifications of 200X and 400X.

\section{Determination of physical and chemical parameters of water}

Monthly temperature $\left({ }^{\circ} \mathrm{C}\right), \mathrm{pH}$, salinity (psu), dissolved oxygen ( $\left.\mathrm{mg} \mathrm{L}^{-1}\right)$ and chlorophyll $a\left(\mu \mathrm{g} \mathrm{L}^{-1}\right)$ in Calich Lagoon water from February 2019 to May 2019 were recorded in situ with a multiparameter probe (Ocean Seven 316 Plus CTD, Idronaut, Brugherio, Italy).

\section{Shellfish samples}

Two mussel samples composed of 60 M. galloprovincialis specimens each, were collected in February 2019 and in May 2019 from one sampling point of the experimental pilot farm (Figure 1). All samples were stored in refrigerated bags and immediately brought to the laboratories to be analyzed within 24 hours.

\section{Toxin analyses}

Starting from shellfish tissue, according to the AOAC 2005 Official Method 2005.06, the determinations of PSP toxins were performed. The LTs toxins were analysed according to the Regulation (EC) $15 / 2011$ by means the liquid chromatography-tandem mass spectrometry approach (LC-MS/MS). The extraction procedure is reported in AESAN EU-RL-MB Lipophilic toxins Version 5: 2015.

Finally, the DO acid was detected

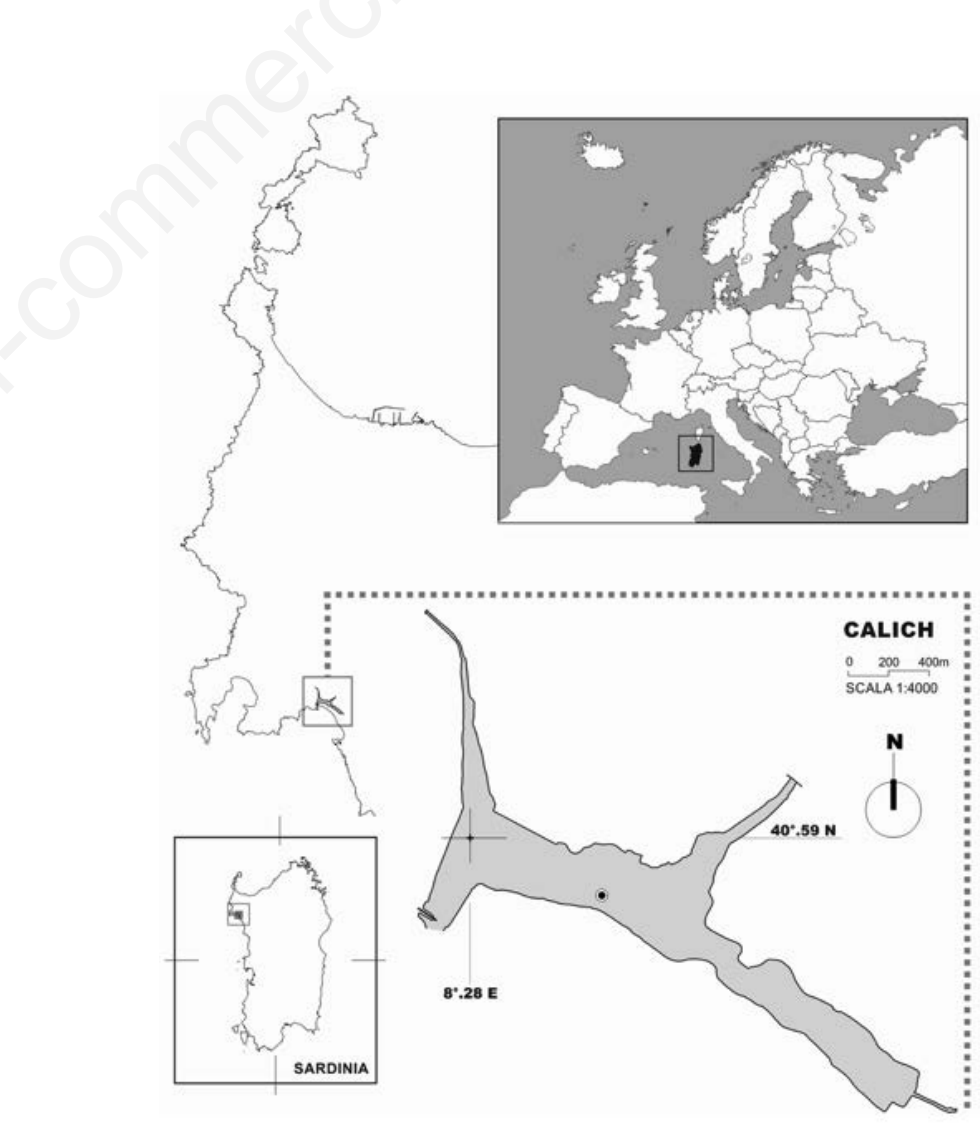

Figure 1. Study area. 
according to the Standard Operating Procedure AESAN, 2008. The description of the methods has been previously described in Mudadu et al., 2021.

\section{E. coli}

The enumeration of $E$. coli was conducted on $100 \mathrm{~g}$ of sample using the Most Probable Number (MPN) method (ISO 16649-3) according to Bazzoni et al., 2019.

\section{Salmonella spp.}

The analyses were performed according to the ISO 6579-1:2017. The description of the method has been previously described in Bazzoni et al., 2019.

\section{Vibrio spp.}

The analyses for the determination of Vibrio spp. were performed according to the ISO/TSS 21872-1-2:2017 method with two pre-enrichment steps. The method has been previously reported in Lorenzoni et al., 2021.

\section{Microplastics}

The determination of MPs in mussels was performed according to an internal protocol based on Phuang et al. (2018). The digestion efficiency and the recovery rate have been determined according to Karami et al., 2017. These values have been calculated as follows:

$$
\text { Digestion efficiency }(\%)=\frac{W i-(W a-W b)}{W i} \times 100
$$

$\mathrm{Wi}=$ Initial weight of biological materials; $\mathrm{Wa}=$ Weight of dry filter membrane after filtration.

$\mathrm{Wb}=$ Weight of dry filter membrane before filtration.

$$
\text { Recovery rate }(\%)=\frac{W a-W b}{W i} \times 100
$$

Wa $=$ Weight of dry filter membrane after filtration, and $\mathrm{Wb}=$ Weight of dry filter membrane before filtration, and $\mathrm{Wi}=$ Initial weight of spiked MPs.

The MPs determination was performed only in May, because the mussels from the previous sampling in February 2019 were used to test the protocol. Samples were col- lected, immediately posed in cooled bags and transported to the laboratory of the Istituto Zooprofilattico Sperimentale della Sardegna within two hours of collection. The samples were frozen at $-20^{\circ} \mathrm{C}$ until analysis. Our method was based on the use of a stereomicroscope as a first step for a preliminary evaluation of items that potentially could have been made of plastics. All mussels were firstly rinsed with distilled water. Each sample was composed by 3 mussels randomly selected. During the experiment were considered 2 groups of mussels, called group A and group B. Length, width and weight of each mussel was determined. $\mathrm{KOH}$ 10\% (Potassium Hydroxide Pellets, Carlo Erba, Milano, Italy) was added in each flask, the $\mathrm{KOH}$ quantity was determined on the basis of the weight difference of the flask with muscle tissue minus the weight from empty flask and the value obtained was multiplied by 3. For each group was prepared a procedural blank (WH), which was a sample with $\mathrm{KOH} 10 \%$ without mussels. In addition, to assess the possible presence of items in the laminar flow hood, a filter was placed in a glass Petri dish located near the workstation. The flasks were stored to $48 \mathrm{~h}$ at $60^{\circ} \mathrm{C}$. Afterwards the samples were filtered using $5 \mu \mathrm{m}$ nitrocellulose filters and 47-50 $\mathrm{mm}$ in diameter (Merck TM SSWP04700), with the aid of a vacuum pump (Thermo Savant VLP200 Valu Pump, Thermo Fischer Scientific, USA). Consequently, filters were placed in glass petri dishes and allowed to dry at room temperature for 24 hours. As a final step, filters were observed by means a stereomicroscope (LEICA M205 C, Microsystems Gmbh, Germany). MPs were classified according to a morphologic classification, by shape (sphere, fiber, fragment, etc.) and color (white, black, red, blue, green, other colors, transparent, opaque, etc.), and counted. Several characteristics should be indicative of a non-biologic origin. Major plastic features are the absence of repetitive structures indicative of biological origin, homogeneous colouring unless due to transparency, and in case of fibrous forms equal thickness and threedimensional bending (Enders et al., 2015).

\section{Results}

\section{Determination of physical-chemical parameters of water}

Table 1 shows the values of temperature, salinity, dissolved oxygen, concentration of chlorophyll $a$ and $\mathrm{pH}$ of the water, recorded by means of a multiparametric probe at the experimental pilot plant. The values of salinity, dissolved oxygen and $\mathrm{pH}$ were in the desirable ranges for lagoon shellfish areas and appeared almost always within the survival limits of $M$. galloprovincialis (Specchiulli et al., 2008; Serra et al., 2011).

\section{Phytoplankton community and biotoxins}

Between February to May 2019, a total of 24 taxa were observed (Table 2). The "Ultraplankton", a category with organisms too difficult to classify because of their small size $(<5 \mu \mathrm{m}$; Murphy and Hagen, $1985)$, is also considered. The mostly represented class was Bacillariophyceae, with 17 taxa. Other classes were Dinophyceae (3 taxa), Cryptophyceae (1), Dictyophyceae (1), Chlophyceae (1) and Pyramimonadophyceae (1). The highest abundances were observed in March, with in a peak of Cyclotella sp. $\left(57 \times 10^{6}\right.$ cells/L) and Skeletonema costatum $\left(41 \times 10^{6}\right.$ cells/L). Ultraplankton was always present with abundances relevant throughout the period considered, with a peak in May $\left(95 \times 10^{6}\right.$ cells/L). No potentially toxic algae were found, moreover no biotoxins were found in mussels.

\section{Bacteria}

E. coli was found with a concentration of $16000 \mathrm{MPN} / 100 \mathrm{~g}$ in February and 1300 MPN/100 g in May. Salmonella spp. and Vibrio spp. were never detected.

\section{Microplastics}

The digestion efficiency was $96 \%$ and the recovery rate was $95 \%$. In all groups of mussels were detected fibers, while fragments were found more rarely. Items were found in both May sampling groups (18 items in group A and 21 items in group B) and the results are summarized in Table 3. As shown in Table 4, an average of one item per grams of muscle has been pointed out.

\begin{tabular}{|c|c|c|c|c|c|c|}
\hline Month & Depth (cm) & Water temperature $\left({ }^{\circ} \mathrm{C}\right)$ & Salinity (psu) & Oxigen (mg L-1) & Chlorophyll a ( g L $\left.\mathbf{L}^{-1}\right)$ & $\mathrm{pH}$ \\
\hline February & 60 & 10.7 & 1.8 & 4.4 & 1.3 & 7.9 \\
\hline March & 60 & 14.8 & 18.3 & 7.1 & 1.95 & 8.2 \\
\hline April & 60 & 17 & 32.3 & 6.4 & 1.15 & 8.6 \\
\hline May & 60 & 14 & 23.5 & 7 & 0.71 & 9 \\
\hline
\end{tabular}

Table 1. Determination of physical-chemical parameters and concentration of chlorophyll $a$ in Calich Lagoon's water in 2019. 
No potentially harmful algae, able to

\section{Discussion and conclusions}

This paper reports the results on the determination of phytoplankton in water samples, algal and their biotoxin, microbiological parameters and MPs in Mediterranean mussels from an experimental pilot farm in the Calich Lagoon (Sardinia, Italy), a brackish environment located in an area of strong anthropogenic impact. determine PSP, DSP or ASP events, has been detected. Several classes have been found, in particular Bacillariophyceae. Microalgae are a food source for mussel population and Bacillariophyceae represent a well know source of food for bivalve molluscs (Muniz et al., 2017).

According to the Regulation EU $625 / 2017$ and the implementing regulation $627 / 2019$ regarding the microbiological quality for the production and placing on the market of bivalve molluses, the overall results of the present study suggested a possible classification of the Calich Lagoon as Zone B. However, the seasonal fluctuations of E.coli counts in mussels should be continuously monitored, Salmonella spp. and Vibrio spp. were not found in shellfish samples collected in spring. On the contrary, Bazzoni et al. (2019) detected these bacterial pathogens in spring sampling sessions.

Table 2. List of Phytoplankton taxa and species detected with relative cellular abundances (cells/L) from February to May 2019 in the Calich Lagoon (Sardinia).

\begin{tabular}{|c|c|c|c|c|c|}
\hline Algal Class & Algal species & February & March & April & May \\
\hline Bacillariophyceae & $\begin{array}{l}\text { Achnanthes sp. } \\
\text { Amphora sp. } \\
\text { Chaetoceros subtilis } \\
\text { Chaetoceros tenuissimus } \\
\text { Cocconeis sp. } \\
\text { Cyclotella sp. } \\
\text { Fragilaria sp. } \\
\text { Licmophora sp. } \\
\text { Melosira spp. } \\
\text { Melosira varians } \\
\text { Navicula spp. } \\
\text { Nitzschia sp. } \\
\text { Skeletonema costatum } \\
\text { Synedra sp. } \\
\text { Thalassiosira sp. } \\
\text { Tryblionella sp. } \\
\text { Entomoneis sp. }\end{array}$ & $\begin{array}{l}<300 \\
3893 \\
<300 \\
<300 \\
<300 \\
<300 \\
3142 \\
<300 \\
11458 \\
2083 \\
7663 \\
<300 \\
<300 \\
<300 \\
7663 \\
61430 \\
<300\end{array}$ & $\begin{array}{c}<300 \\
<300 \\
756146 \\
<300 \\
<300 \\
55898550 \\
<300 \\
<300 \\
2049 \\
<300 \\
7197 \\
7661 \\
4121077 \\
992 \\
3074 \\
<300 \\
<300\end{array}$ & $\begin{array}{c}400 \\
3958 \\
117054 \\
3958 \\
32458 \\
198294 \\
<300 \\
<300 \\
600 \\
<300 \\
23373 \\
<300 \\
949057 \\
100 \\
<300 \\
<300 \\
<300\end{array}$ & $\begin{array}{l}<300 \\
<300 \\
642576 \\
<300 \\
491570 \\
19773 \\
<300 \\
9500 \\
<300 \\
<300 \\
4750 \\
15797 \\
<300 \\
<300 \\
116320 \\
<300 \\
<300\end{array}$ \\
\hline Dinophyceae & $\begin{array}{l}\text { Gymnodinium sp. } \\
\text { Kryptoperidinium foliaceum } \\
\text { Minuscola bipes }\end{array}$ & $\begin{array}{l}<300 \\
<300 \\
<300\end{array}$ & $\begin{array}{c}<300 \\
11075 \\
7197\end{array}$ & $\begin{array}{l}<300 \\
<300 \\
<300\end{array}$ & $\begin{array}{l}5523 \\
<300 \\
<300\end{array}$ \\
\hline Chlorophyceae & Tetraselmis sp. & $<300$ & $<300$ & 3958 & 23750 \\
\hline Cryptophyceae & undetermined Cryptophyceae & 11433 & 965555 & 484500 & 141396 \\
\hline Dictyophyceae & Apedinella spinifera & $<300$ & $<300$ & 15323 & $<300$ \\
\hline Pyramimonadophyceae & Pyramimonas sp. & $<300$ & 183174 & $<300$ & $<300$ \\
\hline ultraplankton & $2+2$ & 17367188 & 13364022 & 51471000 & 95285000 \\
\hline
\end{tabular}

$<300$ cells/L = detection limited

Table 3. Type and quantity of microplastics in Calich Lagoon's mussels in May 2019.

\begin{tabular}{lccc} 
Mussels group A & Quantity & Mussels group B & Quantity \\
Light blue fiber & 6 & Light blue fiber & 14 \\
Dark blue fiber & 6 & Dark blue fiber & 4 \\
\hline Red fiber & 1 & Red fiber & 2 \\
Dark fiber & 3 & Dark fiber & n.d \\
Transparent white & 2 & Transparent white & n.d \\
Fragments & n.d & Fragments & 1 \\
\hline
\end{tabular}

n.d: not detected

Table 4. Ratio of MPs found to the weight of the sample analysed.

\begin{tabular}{|c|c|c|c|c|c|c|c|c|c|c|}
\hline $\begin{array}{l}\text { Sampling } \\
\text { data }\end{array}$ & $\begin{array}{c}\text { Weight (g) } \\
\text { Group A }\end{array}$ & $\begin{array}{l}\text { Length (cm) } \\
\text { Group A }\end{array}$ & $\begin{array}{c}\text { Width (g) } \\
\text { Group A }\end{array}$ & $\begin{array}{c}\text { Weight (g) } \\
\text { Group B }\end{array}$ & $\begin{array}{c}\text { Length (cm) } \\
\text { Group B }\end{array}$ & $\begin{array}{c}\text { Width (g) } \\
\text { Group B }\end{array}$ & $\begin{array}{l}\text { Total Weight } \\
\text { group A } \\
\text { (g) }\end{array}$ & $\begin{array}{c}\text { MPs/grams } \\
\text { of muscle } \\
\text { group A }\end{array}$ & $\begin{array}{c}\text { Total Weight } \\
\text { group B } \\
\text { (g) }\end{array}$ & $\begin{array}{c}\text { MPs/grams } \\
\text { of muscle } \\
\text { group B }\end{array}$ \\
\hline 6/5/2019 & $\begin{array}{l}7.9 \\
4.9 \\
5.3\end{array}$ & $\begin{array}{c}49.6 \\
45.02 \\
45.23\end{array}$ & $\begin{array}{l}26.40 \\
25.26 \\
23.35\end{array}$ & $\begin{array}{l}4.8 \\
5.1 \\
4.5\end{array}$ & $\begin{array}{l}44.04 \\
45.47 \\
46.00\end{array}$ & $\begin{array}{l}21.63 \\
23.66 \\
22.26\end{array}$ & 17.5 & 1.02 & 14.4 & 1.45 \\
\hline
\end{tabular}


In recent years, MPs have aroused interest in the scientific community, in particular for their presence in the digestive system and in the tissues of marine species. Our results showed that both concentration and type of the detected items (mainly fibers) were similar in the two batches. According to previous authors (Avio et al., 2015, Corami et al.,2020) they confirmed the capacity of MPs accumulation in the mussels. Mussels may be utilized to assess the abundance of MPs in the marine environment. At present, no specific national or European legislation indicated the maximum levels of MPs that can be found in the tissues of bivalves intended for human consumption. The role of mussels as source of MPs for humans is still scanty and a real evaluation of the human risk due to the MPs ingestion in mussels is still under investigation (Catarino et al., 2018, Barboza et al., 2018). The airborne MPs contamination should be considered as a major risk for the human health (Prata, 2018).

\section{References}

AOAC, 2005. Paralytic shellfish poisoning toxins in shellfish pre chromatographic oxidation and liquid chromatography with fluorescence detection. J AOAC Int 88:1714-32.

Arthur C, Baker J, Bamford H, 2009. In Proceedings of the International Research Workshop on the Occurrence, Effects and Fate of Microplastic Marine Debris, NOAA Technical Memorandum NOS-OR \& R-30.NOAA (p. 530). Silver Spring, September 9-11, 2008.

Avio CG, Gorbi S, Milan M, Benedetti M, Fattorini D, d'Errico G, Pauletto M, Bargelloni L, Regoli F, 2015. Pollutants bioavailability and toxicological risk from microplastics to marine mussels. Environ Pollut 198:211-22.

Baralla E, Varoni MV, Sedda T, Pasciu V, Floris A, Demontis MP, 2017. Microcystins Presence in Mussels (M. galloprovincialis) and Water of Two Productive Mediterranean's Lagoons (Sardinia, Italy). Biomed Res Int 2017:3769245.

Barboza LGA, Vethaak DA, Lavorante BRBO, Lundebye AK, Guilhermino L. 2018. Marine microplastic debris: An emerging issue for food security, food safetyand human health. Marine Pollut Bulle 133:336-48.

Bazzoni AM, Mudadu AG, Lorenzoni G, Soro B, Bardino B, Arras I, Sanna G, Vodret B, Bazzardi R, Marongiu E, Virgilio S, 2018. Detection of Dinophysis species and associated
Okadaic acid in farmed shellfish: a twoyear study from the western Mediterranean area. J Vet Res 62.

Bazzoni AM, Mudadu AG, Esposito G, Urru R, Ortu S, Mara L, Uda MT, Arras I, Lorenzoni G, Sanna G, Bazzardi R, Marongiu E, Virgilio S, 2019. Bacterial and Viral Investigations Combined with Determination of Phytoplankton and Algal Biotoxins in Mussels and Water from a Mediterranean Coastal Lagoon (Sardinia, Italy). J Food Prot 82:150111.

Caburlotto G, Bianchi F, Gennari M, Ghidini V, Socal G, Aubry FB, Bastianini M, Tafi MC, Lleo MM, 2011. Integrated evaluation of environmental parameters influencing Vibrio occurrence in the coastal northern Adriatic Sea (Italy) facing the Venetian Lagoon. Microb Ecol 63:20-31.

Cannas A, Manca S, Trentadue M, Fois N, 2011. Population structure of carpet shell clam (Ruditapes decussates L.) in two coastal lagoons of Sardinia (Italy). Biol Mar Mediterr 18:298-9.

Catarino AI, Macchia V, Sanderson WG, Thompson RC, Henry TB, 2018. Low levels of microplastics (MP) in wild mussels indicate that MP ingestion by humans is minimal compared to exposure via household fibres fallout during a meal. Environ Pollut 237:675-84.

Cataudella S, Crosetti D, Massa F, 2015. Mediterranean coastal lagoons: sustainable management and interactions among aquaculture, capture fisheries and the environment. Studies and reviews no. 95. Food and Agriculture Organization of the United Nations, Rome.

Chessa LA, Paesanti F, Pais A, Scardi M, Serra S, Vitale L, 2005. Perspectives for development of low impact aquaculture in a Western Mediterranean lagoon: the case of the carpet clam Tapes decussatus. Aquac Int 13:147-55.

Chessa LA, Casola E, Lanera P, Pais A, Plastina N, Serra S, Scardi M, Valiante LM, Vinci D, 2007. Is there a correspondence between dominant trophic group in benthic and fish fauna of the Calich Lagoon? Biol Mar Mediterr 14:290-1.

Corami F, Rosso B, Bravo B, Gambaro A, Barbante C, 2020. A novel method for purification, quantitative analysis and characterization of microplastic fibers using Micro-FTIR. Chemosphere 238:124564.

EFSA and ECDC, 2021. The European Union One Health 2019 Zoonoses Report Volume19, Issue 2. February 2021. European Safety Authority and European Centre for Disease Prevention and Control (EFSA and ECDC).

Enders K, Lenz R, Stedmon CA, Nielsen TG, 2015. Abundance, size and polymer composition of marine microplastics $\geq 10 \mu \mathrm{m}$ in the Atlantic Ocean and their modelled vertical distribution. Mar Pollut Bull 100:70-81.

Esposito G, Meloni D, Abete MC, Colombero G, Mantia M, Pastorino P, Prearo M, Pais A, Antuofermo E, Squadrone S, 2018. The bivalve Ruditapes decussatus: a biomonitor of trace elements pollution in Sardinian coastal lagoons (Italy). Environ Poll 242:1720-8.

Esposito G, Mudadu AG, Abete MC, Pederiva S, Griglione A, Stella C, Ortu S, Bazzoni AM, Meloni D, Squadrone S, 2021. Seasonal accumulation of trace elements in native Mediterranean mussels (Mytilus galloprovincialis Lamarck, 1819) collected in the Calich Lagoon (Sardinia, Italy). Environ Sci Pollut Res 28:9.

European Union Reference Laboratory for Marine (EU-RL-MB). Agencia Española de Consumo, Seguridad Alimentaria y Nutrición(AESAN). Lipophilic Toxins: Blooms in the Sea; Elsevier Science Publishers: Amsterdam, The Netherlands, 2015; pp. 469-474.

European Union Reference Laboratory for Marine (EU-RL-MB), Agencia Española de Consumo, Seguridad Alimentaria y Nutrición (AESAN). EUHarmonised Standard Operating Procedure for Determination of Domoic Acid in Shellfish and Finfish by RPHPLC Using UV Detection; AESAN: Vigo, Spain, 2008.

EUMOFA, European Monitoring Centre for the fishery and aquaculture products. https://www.eumofa.eu/it/the-eu-market. Accessed 1 Jun 2021.

Fenza A, Olla G, Salati F, Viale I, 2014. Stagni e lagune produttive della Sardegna. Tradizioni sapori ed ambiente. Agenzia Regionale LAORE Sardegna, pp. 1-73.

Ielmini SE, Piredda G, Mura S, Greppi GF, 2014. Protein biomarkers as indicator for water pollution in some lagoons of Sardinia (Italy). Transit Waters Bull $8: 32-52$.

International Organization for Standardization. 2017. ISO 21872$1: 2017$. Microbiology of the food chain-horizontal method for the determination of Vibrio spp. Part 1. Detection of potentially enteropathogenic Vibrio parahaemolyticus, Vibrio cholerae and Vibrio vulnificus. International Organization for 
Standardization, Geneva.

International Organization for Standardization. 2017. ISO 65791:2017. Microbiology of the food chain - Horizontal method for the detection, enumeration and serotyping of Salmonella -Part 1: Detection of Salmonella spp. International Organization for Standardization, Geneva.

Karami A, Golieskardi A, Choo CK, Romanoc N, Bin HY, Babak S, 2017. A high-performance protocol for extraction of microplastics in fish. Sci Total Environ 578:485-94.

Lorenzoni G, Tedde G, Mara L, Bazzoni AM, Esposito G, Salza S, Piras G, Tedde T, Bazzardi R, Arras I, Uda MT, Virgilio S, Meloni D Mudadu AG, 2021. Presence, Seasonal Distribution, and Biomolecular Characterization of Vibrio parahaemolyticus and Vibrio vulnificus in Shellfish Harvested and Marketed in Sardinia (Italy) between 2017 and 2018. J Food Prot 84:154954.

Mudadu AG, Bazzoni AM, Congiu V, Esposito G, Cesarani A, Melillo R, Lorenzoni G, Cau S, Soro B, Vodret B, Meloni D, Virgilio S, 2021. Longitudinal Study on Seasonal Variation of Marine Biotoxins and Related Harmful Algae in Bivalve Mollusks Bred in Sardinia (Italy, W Mediterranean Sea) from 2015 to 2020 and Assessment of Potential Public Health Risks. J Mar Sci Eng 9:510.

Muñiz O, Revilla M, Rodríguez JG, LazaMartínez A, Seoane S, Franco J, Orive E, 2017. Evaluation of phytoplankton quality and toxicity risk based on a long-term time series previous to the implementation of a bivalve farm (Basque coast as a case study). Reg Stud Mar Sci 10:10-19.

Murphy LS and Hagen EM, 1985. The distribution and abundance of phototrophic ultraplankton in the North Atlantic. Limnol Oceanogr 30:47-58.

Noble RT, Lee IM, Schiff KC, 2004. Inactivation of indicator micro-organisms from various sources of faecal contamination in seawater and freshwater. J Appl Microbiol 96:464-72.

Pais A, Chessa LA, Serra S, Ruiu A, 2006. An alternative suspended culture method for the Mediterranean carpet clam, Tapes decussatus (L.), in the Calich Lagoon (north-western Sardinia). Biol Mar Mediterr 13:134-5.

Pais A, Chessa LA, Serra S, Ruiu A, Meloni G, 2007. Suspended culture of Ostrea edulis in the Calich Lagoon (north-western Sardinia, Italy): preliminary results.
Ital J Anim Sci 6:810.

Phuong NN, Poirier L, Phan QT, Lagarde F, Zalouk-Vergnoux A, 2018. Factors influencing the microplastic contamination of bivalves from the French Atlantic coast: Location, season and/or mode of life? Mar Pollut Bull 129:66474.

Prata JC, 2018. Airborne microplastics: Consequences to human health? Environmental Pollution 234:115-26.

Pulina S, Satta CT, Padedda BM, Bazzoni AM, Sechi N, Lugliè A, 2017. Picophytoplankton seasonal dynamics and interactions with environmental variables in three Mediterranean coastal lagoons. Estuar Coasts 40:469-78.

Pulina S, Satta CT, Padedda BM, Sechi N, Lugliè A, 2018. Seasonal variations of phytoplankton size structure in relation to environmental variables in three Mediterranean shallow coastal lagoons. Estuar Coast Shelf Sci 212:95-104.

Regulation (EC) No 2073/2005 of 15 November 2005 on microbiological criteria for foodstuffs. Available online: https://eur-lex.europa.eu/legal content/EN/ALL/?uri=CELEX\%3A32005 R2073 (accessed on 20 May 2021).

Regulation (EC) No 15/2011 of 10 January 2011 amending Regulation (EC) No 2074/2005 as Regards Recognised Testing Methods for Detecting marine biotoxins in Live Bivalve Molluscs. Available online: https:/eurlex.europa.eu/eli/reg/2011/15/oj. (accessed on 20 June 2021).

Regulation (EU) No 2017/625 of the European Parliament and of the Council of 15 March 2017 on official controls and other official activities performed to ensure the application of food and feed law, rules on animal health and welfare, plant health and plant protection products, amending Regulations (EC) No 999/2001, (EC) No 396/2005, (EC) No $1069 / 2009$, (EC) No 1107/2009, (EU) No 1151/2012, (EU) No 652/2014, (EU) 2016/429 and (EU) 2016/2031 of the European Parliament and of the Council, Council Regulations (EC) No $1 / 2005$ and (EC) No 1099/2009 and Council Directives 98/58/EC, 1999/74/EC, 2007/43/EC, 2008/119/EC and 2008/120/EC, and repealing Regulations (EC) No $854 / 2004$ and (EC) No 882/2004 of the European Parliament and of the Council, Council Directives 89/608/EEC, 89/662/EEC, 90/425/EEC, 91/496/EEC, 96/23/EC, 96/93/EC and 97/78/EC and Council Decision 92/438/EEC (Official Controls Regulation)Text with EEA relevance. Available online: https://eur1 e $\mathrm{x}$. e u r o p a . e u / 1 e g a 1 content/EN/TXT/?uri=celex\%3A32017 R0625 (accessed on 07 June 2021).

Regulation (EC) No 2019/627 of 15 March 2019 laying down uniform practical arrangements for the performance of official controls on products of animal origin intended for human consumption in accordance with Regulation (EU) 2017/625 of the European Parliament and of the Council and amending Commission Regulation (EC) No 2074/2005 as regards official controls. Available online: https://eurlex.europa.eu/eli/reg_impl/2019/627/oj (accessed on 07 June 2021).

Satta CT, Pulina S, Reñé A, Padedda BM, Caddeo T, Fois N, Lugliè A, 2020. Ecological, morphological and molecular characterization of Kryptoperidinium sp. (Dinophyceae) from two Mediterranean coastal shallow lagoons. Harmful Algae 97:101855.

Sedda T, Baralla E, Varoni MV, Pasciu V, Lorenzoni G, Demontis MP, 2016. Determination of microcystin-LR in clams (Tapes decussatus) of two Sardinian coastal ponds (Italy). Mar Pollut Bull 108:317-20.

Serra S, Chessa G, Saba S, Trentadue M, Manca S, Chessa F, Fois N, Pais A, 2011. Comparative growth of the Mediterranean Mussel (Mytilus galloprovincialis Lamarck, 1819) reared in three coastal areas of Sardinia. Ital J Anim Sci 10:55-6.

Specchiulli A, Focardi S, Renzic M, Scirocco T, Cilenti L, Breber P, Bastianoni S, 2008. Environmental heterogeneity patterns and assessment of trophic levels in two Mediterranean lagoons: Orbetello and Varano, Italy. Sci Total Environ 402:285-98

Shah AS, Hasan F, Haneed A, Ahmed S, 2008. Biological degradation of plastics: A comprehensive review. Biotechnol Adv 26:246-5.

Tsangaris C, Panti C, Compa M, Pedà C, Digka N, Baini M, D'Alessandro M, Alomar C, Patsiou D, Giani D, Romeo T, Deudero S, Fossi MC, 2021. Interlaboratoy comparisono of microplastic extraction methods from marine biota tissues: A harmonization exercise of the Plastic Busters MPAs project. Mar Pollut Bull 164:111992.

Tirado MC, Clarke R, Jaykus LA, McQuattersGollop A, and Frank JM, 2010. Climate change and food safety: a review. Food Res Int 43:1745-65.

Thompson JR, Randa MA, Marcelino LA, Tomita-Mitchell A, Lim EA, and Polz MF, 2004. Diversity and dynamics of a North Atlantic coastal Vibrio comm- 
unity. Appl Environ Microbiol 70:4103-10.

Thompson RC, Swan SH, Moore CJ, Vom Saal FS, 2009. Our plastic age. Philosophical Transactions of the Royal Society B: Biol Sci 364:1973-6.

UNI EN 15204. European Standard. Water Quality - Guidance Standard for the
Routine Analysis of Phytoplankton Abundance and Composition Using Inverted Microscopy (Utermöhl Technique) CEN Management Centre, Brussels (2006), pp. 1-40.

Utermöhl, H. 1958. Zurvervollkommung der quantitativen phytoplankton-methodik. Verh Int Verein Theor Angew
Limnol 9:1-39.

Wu D, Chen J, He X, Wang J, Wang Z, Li X, Wang B, 2019. Distribution, partitioning, and seasonal variation of lipophilic marine algal toxins in aquatic environments of a typical semi-closed mariculture bay. Environ Pollut 255:113299. 